\title{
Heřmanský-Pudlák syndrome: A case report
}

\author{
Sonali Someek Basu, Pranav Kumar
}

\begin{abstract}
Heřmanský-Pudlák syndrome (HPS) is hereditary multi system, a rare autosomal recessive disorder with heterogeneous locus characterized by tyrosine positive oculocutaneous albinism, congenital nystagmus, platelet storage pool deficiency hemorrhagic bleeding tendency and systemic manifestations due to lysosomal accumulation of ceroid lipofuscin in different organs includes pulmonary fibrosis and granulomatous enteropathy colitis and renal failure. Depending upon the organ system symptoms and signs, the presentation of HPS can be varied and diagnosis can be challenging. The most frequently used criteria for diagnosis of HPS as per National Organization of Rare Disease (NORD) revised 2015 are albinism and prolong bleeding. Symptoms due to ceroid lipofuscin deposition in lungs, colon, heart and kidneys can occur. Differentiating this condition from other diseases that cause oculocutaneous albinism such as ocular albinism, Griscelli syndrome and Chédiak-Higashi syndrome by presence of neurological symptoms and frequent bacterial infections due to immunodeficiency and analysis of peripheral blood smear with prolong bleeding time. Also gene study differentiates these conditions. Early diagnosis is crucial to prevent complications associated with HPS by supportive
\end{abstract}

Sonali Someek Basu ${ }^{1}$, Pranav Kumar ${ }^{2}$

Affiliations: ${ }^{1}$ BPT Registrar, FRACP, Mackay Base Hospital, Queensland Health, Australia; ${ }^{2}$ FRACP Respiratory Physician, Mackay Base Hospital, Queensland Health, Australia.

Corresponding Author: Dr. Pranav Kumar, Mackay Base Hospital, 475 Bridge Road, Mackay, Queensland 4740, Australia; Email: drpranavkumar@gmail.com

Received: 16 November 2017

Accepted: 23 January 2018

Published: 01 February 2018 care, rehabilitation and multidisciplinary team approach.

Keywords: Gene and data base, HeřmanskýPudlák syndrome, Multiple skin cancer, Oculocutaneous albinism, Pulmonary fibrosis

\section{How to cite this article}

Basu SS, Kumar P. Heřmanský-Pudlák syndrome: A case report. Int $J$ Case Rep Images 2018;9:100886Z01SB2018.

Article ID: 100886Zo1SB2018

$* * * * * * * * *$

doi: 10.5348/100886Zo1SB2018CR

\section{INTRODUCTION}

Heřmanský-Pudlák syndrome (HPS), a rare hereditary disease caused by autosomal recessive inheritance, was first described by Hermansky and Pudlakin 1959 [1]. Since, then many patients with this autosomal recessive syndrome have been reported. Most are of Dutch or Puerto Rican ancestry, but sporadic cases have appeared all over the world. In Puerto Rico, 5 out of 6 patients with oculocutaneous albinism are shown to have HPS type 1 [2]. Heřmanský-Pudlák syndrome gene can be identified by positional cloning. Homozygous frameshift in HPS gene found in Puerto Rican, Swiss, and Irish and Japanese HPS patients [3]. Northwestern quarter of island has highest prevalence of HPS reported was at least one in 1,800 persons had HPS, and approximately 1 in 21 were carriers [4].

Mortality affects Heřmanský-Pudlák syndrome diagnosed patients between age 30-50 mainly due to lifethreatening complications from $68 \%$ of restrictive lung disease, $17 \%$ of hemorrhage and $15 \%$ of granulomatous colitis [5]. 


\section{EDORiUM Journals}

Biogenesis of lysosome-related organelles complex (BLOC) 1 to 3 are three multiprotein complexes are subunits of HPS gene (Table 1) [6, 7]. Human HPS subtypes sharing same mutation of BLOC resemble each other phenotypically [8]. Deficiencies in these lysosome related organelle implicates in pathogenesis of HPS clinical features [9].

Endomembrane organelle matures requires via fusion with membrane transport intermediates and recycling of fusion factors to their sites of origin by cargo delivery. Melanosomes and other lysosome-related organelles obtained contents from early endosomes which has unknown mechanism of fusion material and its recycling.

Vesicle-associated membrane protein (VAMP7localizes to melanosomes and carries out melanosome cargo trafficking and pigmentation-melanogenesis). VAMP7 functions primarily as V-SNARE in BLOC1-dependent tubular transport from endosomes to melanosomes resulting in melanosomes delivery of BLOC-1-dependent cargoes-TYRP1 (cargo protein TYRP1 requires BLOC-1 for their formation). The fusion of melanosomes with tubular transport carriers mediated by v-SNARE VAMP7. Illumination of SNARE recycling from melanosomes is a critical BLOC-3-dependent step which explains hypopigmentation as a clinical feature in HPS phenotype variants such as BLOC-1 and BLOC- 3 deficiency [10] (Table 1).

Systemic complications in Heřmanský-Pudlák syndrome are associated to accumulation of a ceroid-like substance in lysosomes of a variety of tissues [1].

In this study, we report a case of HPS diagnosed as a result of albinism, nystagmus and multiple excision of skin lesions and interstitial pulmonary fibrosis, easy bruising and episodes of colitis.

\section{CASE REPORT}

A 45-year-old Caucasian male was referred to respiratory outpatient clinic for evaluation of progressive dyspnea. He reports New York Heart Association (NYHA) class II dyspnea since two years. He denies paroxysmal nocturnal dyspnea, orthopnea or leg swelling. Patient has been treated with bronchodilators by general practitioner.

Past medical history of the patient was significant for multiple excision of skin lesion, found out to be squamous cell carcinoma. The patient bruised easily but superficially with minor trauma, and there was no history of blood transfusion. The patient suffered unexplained episodes of bloody diarrhea- an episode of colitis two years ago recovered on antibiotics, colonoscopy revealed inflammation of colon without granulomatous changes. He denied recurrent infections or neurological symptoms.

Family history of the patient was significant. His sister had been diagnosed of albinism and lymphangioleiomyomatosis. His brother had normal skin and was healthy. He was the third child of nonconsanguineous marriage.

There was no history of smoking or alcohol. He was married, staying with wife, had 2 kids -16 years and 11 years, they do not have albinism or ocular features.

On review, pulse rate $78 / \mathrm{min}$ and blood pressure $130 / 78 \mathrm{mmHg}$, saturation $95 \%$ on room air and was afebrile. Marked generalized hypopigmentation-yellow white color of skin and silky fine hair. Eye examination showed photophobia, and exotropia with nystagmus (Figure 1).

Respiratory examination revealed vesicular breath sound and basal fine crepitation.

Table 1: Gene Reviews ${ }^{\circledR}$ by University of Washington, Seattle-Hermansky-Pudlak syndrome genes and databases [7]

\begin{tabular}{llll}
\hline HPS1 & Mutation in the HPS1 gene & Chromosome 10Q24.2 & Protein Block Complex BLOC-3 \\
HPS2 & Mutation in the AP3B1 gene & Chromosome 5Q14 & Protein Block Complex AP-3 \\
HPS3 & Mutation in the HSP3 gene & Chromosome 3Q24 & Protein Block Complex BLOC-2 \\
HPS4 & Mutation in the HSP4 gene & Chromosome 22Q12 & Protein Block Complex BLOC-3 \\
HPS5 & Mutation in the HPS5 gene & Chromosome 11P14 & Protein Block Complex BLOC-2 \\
HPS6 & Mutation in the HPS6 gene & Chromosome 10Q24 & Protein Block Complex BLOC-2 \\
HPS7 & Mutation in the DTNBP1 gene & Chromosome 6P22 & Protein Block Complex BLOC-1 \\
HPS8 & Mutation in the BLOC1S3 gene & Chromosome 19Q13 & Protein Block Complex BLOC-1 \\
HPS9 & Mutation in the PLDN gene & Chromosome 15Q21 & Protein Block Complex BLOC-1 \\
HPS10 & Mutation in the AP3D1 gene & Chromosome 19P13 & Protein Block Complex AP-3 \\
\hline
\end{tabular}

AP-3: Adaptor protein complex-3;

BLOC-1, 2, 3: Biogenesis of lysosome-related organelles complex-1, 2, 3, respectively;

HPS: Heřmanský-Pudlák syndrome. 


\section{EDORIUM Journals}

Cardiovascular, neurological and abdominal examinations were un-remarkable. Blood test full blood count, renal function test and liver function test were normal. Cardiac echocardiogram and renal ultrasonography were normal. Chest X-ray showed few reticulonodular changes in lower lobe bilaterally. High resolution computed tomography (HRCT) chest (Figure 2) indicative of pulmonary fibrosis.

July 2016: FEV1 3.06 (73\%), FVC 3.47 (66\%), FEV1/ FVC 88\%, DLCO 45\%, KCO 72

Feb 2017: FEV1 2.69 (64\%), FVC 3.17 (61\%), FEV1/ FVC 105\%, DLCO 41\%, KCO 68.

Spirometry (Figure 3) showed features of moderate restrictive ventilator pattern, impairment in gas exchange and deterioration in gas transfer from 2016. Examination of the gastrointestinal tract colonoscopy failed to reveal granulomatous colitis. In this patient, gene study proved Heřmanský-Pudlák syndrome (HPS) type VII.
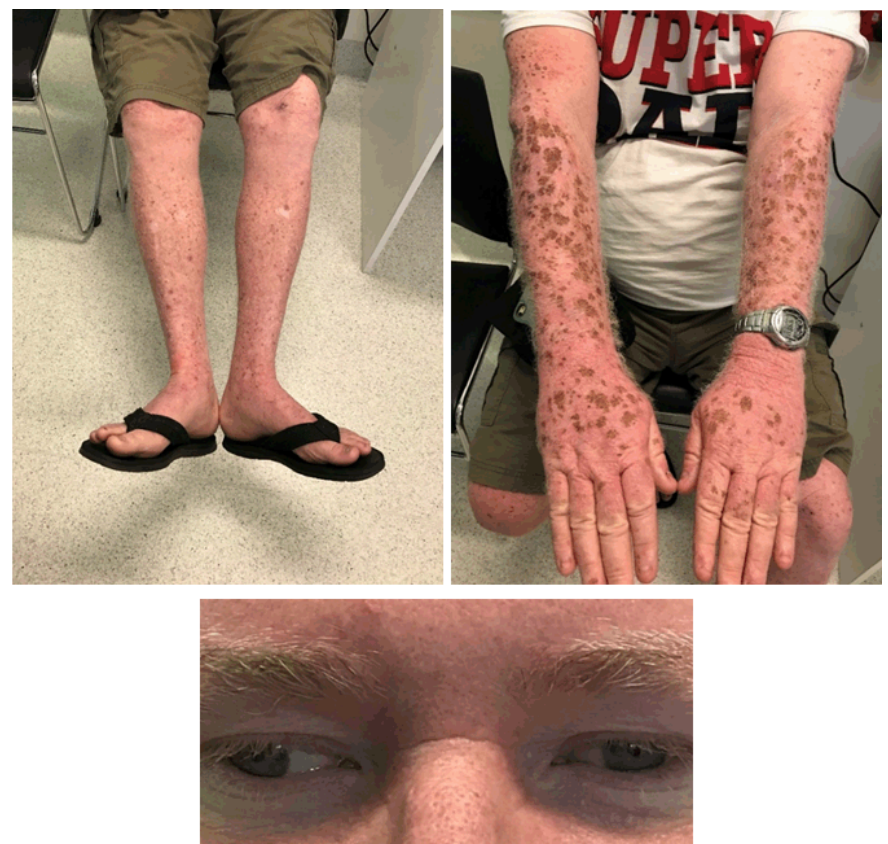

Figure 1: Clinical sign of oculocutaneous albinism and exotropia
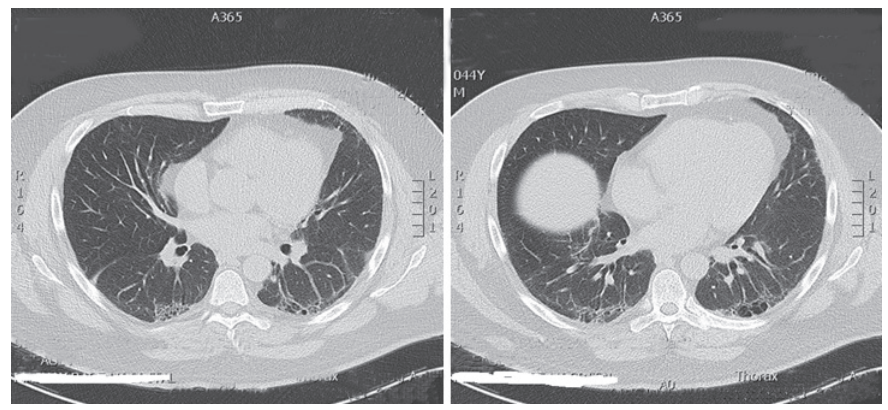

Figure 2: Contrast high resolution computed tomography chestareas of honeycombing which are noted in both the upper lobes peripherally as well as parts of the lower lobe along the posterior aspect. Symmetric areas of fibrosis are seen in both the upper lobes laterally and the lower lobes posteriorly.

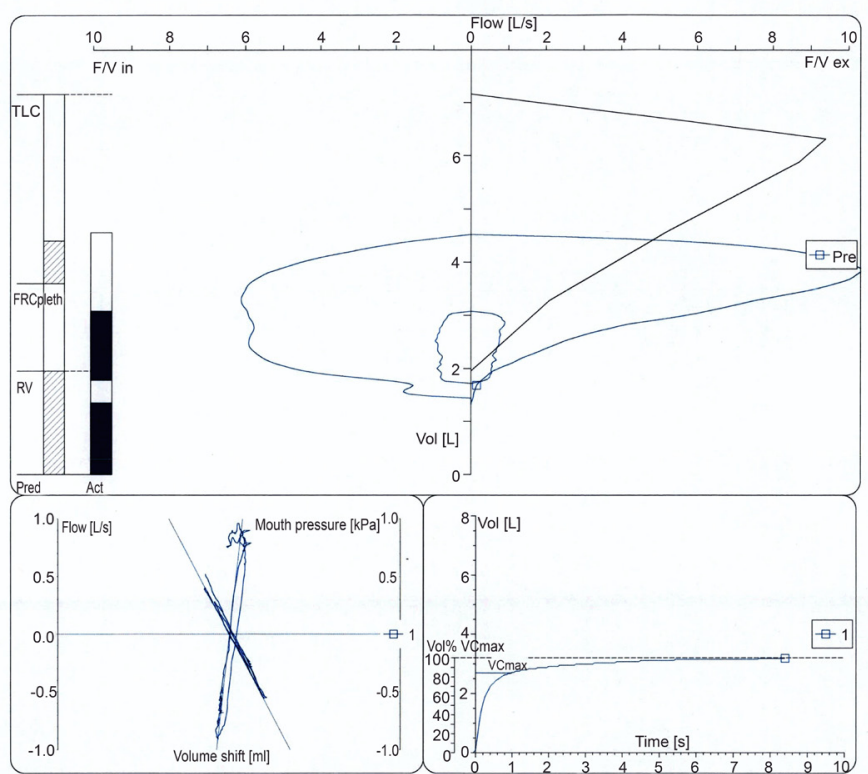

Figure 3: Spirometry pulmonary function test-Moderate restrictive ventilator pattern and impairment in gas exchange.

\section{DISCUSSION}

In this case study, a diagnosis of HeřmanskýPudlák syndrome was considered, based on the external and ocular features of albinism, visual disturbances, interstitial lung disease and past history of easy bruising and episodes of colitis.

There was a study conducted for 49 patients aged from 3-54 years between November 1995 and February 1997 where HSP was diagnosed on the basis of oculocutaneous albinism and storage-pool deficiency (the absence of platelet dense bodies on electron microscopy) [11]. Among those, two patients were exception for diagnostic criteria, they did demonstrate albinism and positive family history of siblings diagnosed of HPS based on criteria.

In the study, molecular testing conducted. One group of Northwest Puerto Rico patients showed homozygous for the 16-bp duplication in exon 15 of the HPS gene, another group of two Puerto Rican and Non-Puerto Ricans showed had no alleles containing the duplication [3].

Syndrome is autosomal recessive, it affects male and females equally. Evidences have mapped the human HPS gene to chromosome segment 10q23 [5] and caused by defects in one of eight genes among HPS1, $\mathrm{AP}_{3} \mathrm{~B} 1$, and HPS3 to HPS8. It has shown molecular variability of HPS revealed in Non-Puerto Rican population by demonstrating other mutations in the HPS1, HPS4 or HPS 5 genes [12]. HPS 1 among Puerto Ricans a 16-bp duplication in exon 15 of the HPS1 gene on chromosome 10 , is the most common [13].

Heřmanský-Pudlák syndrome exhibit wide variation in pigmentation and dermatologic findings [14]. 


\section{EDORiUM Journals}

Periodic alternating Nystagmus is always present in these patients. Strabismus is a common finding in all forms of albinism- esotropia or exotropia [15]. Our patient has periodic alternating nystagmus and exotropia.

To date, 10 human HPS subtypes (HPS-1 to HPS-10) and their associated genes have been identified (Table 1) [16].

HPS10 classified on based of $\mathrm{AP}_{3} \mathrm{~d}$ deficiency that has clinical feature of a severe neurologic disorder with immunodeficiency and albinism [17].

Types 1 and 4 are the most severe forms of the disorder. Types 1, 2, and 4 are the only types associated with pulmonary fibrosis

Individuals with type 3,5 , or 6 have the mildest symptoms. Little is known about the signs, symptoms, and severity of types 7,8 , and 9 [18].

\section{Systemic involvement}

Skin: Albinism is prominent feature of this disorder, but it requires comparison with family members for its detection. The hypopigmentation in HPS is due to impaired melanosome formation, trafficking, or transfer to keratinocytes in contrast to classical albinism which is caused by deficiency of melanosome proteins tyrosine, the $\mathrm{P}$ protein, or TYRP1 which mediates the transformation of tyrosine to the melanin pigment [8]. Squamous cell carcinoma and multiple lesions of actinic keratosis have been reported in HPS patients [19]. Our patient has a history of multiple skin squamous cell carcinoma excisions.

Ocular Involvement: All phenotypes presents with ocular manifestation: nystagmus, strabismus, photophobia, decreased visual acuity, foveal hypoplasia, albinotic fundi and translucent iris. One of the study demonstrated HPS6 diagnosis based on foveal hypoplasia, ocular albinism or OCA though they have mild and late systemic manifestations and a diagnosis of HPS [20].

Retinal and iris pigmentation varies in HPS. The correlation of the macular appearance with the visual acuity may be considered as to assess prognosis. Type 3 HPS have better prognosis in relation to ophthalmic manifestations than type 1 HPS. Type 1 HPS has esotropia and type 3 HPS has exotropia frequently.

In our patient, a detail visual examination added the diagnoses of myopia and strabismus, and glass eye prosthesis was recommended by ophthalmologist.

Platelet Dysfunction: The second component of the disease is a platelet storage pool defect characterized by a bleeding diathesis. The platelets show an absence of dense bodies essential for the second phase of platelet aggregation. This aggregation defect is associated with a deficiency of serotonin, adenine nucleotides, and calcium in the platelet [21]. Functionally, the second phase of platelet aggregation is impaired, producing a prolonged bleeding time, but platelet number, prothrombin time, partial thromboplastin time, fibrinogen level, and clotting factors are all normal [3]. Under classification of thrombocytopathies, Heřmanský-Pudlák syndrome classified under platelet secretion phenotype [22]. Lack of platelet dense bodies on electron microscopy is consistent diagnostic feature of HPS [23].

Pulmonary Fibrosis: Pulmonary fibrosis (PF) is a restrictive lung disease, where symptoms are generally visible in the early thirties. It can progress to death within a decade unless lung transplant is done. Patients with HPS-1, HPS-2, and HPS-4 tend to develop pulmonary fibrosis in Puerto Rico; Almost 100\% of HPS-1 develop HPS-PF. The HPS-PF has similar histological pattern of idiopathic pulmonary fibrosis and is irreversible. The HPS-PF manifest earlier at age often at age of 35-40 years. Macrophage-mediated inflammation has strong evidence and increased numbers of circulating CXCR4positive fibro-cysts, Lamellar bodies responsible for producing surfactant type II LRO type of cells causing dysfunction alveolar epithelial cell plays role in HPSPF pathogenesis. The PS-PF progressed to dyspnea and worsening hypoxia. Lung function test and six minutes walk test for early establishment of oxygen requirement during exercise, HRCT chest for evidence of ground glass opacity and pleural thickening to assess progression is considered in HPS patients. Lung biopsy not indicated due to bleeding diathesis. New antifibrotic drugs, pirfenidone and nintedanib have identified capable of reversing and ameliorate progression of pulmonary fibrosis and lung transplant is life prolonging treatment [24]. Oral pirfenidone for the pulmonary fibrosis of Heřmanský-Pudlák syndrome clinical trial is ongoing National Human Genome Research Institute (NHGRI) since 1999.

Colitis: A granulomatous colitis associated with HPS was first described in 1980 [25]. Twenty percent patients of HPS associated with granulomatous colitis. The HPS types 1 and 4 are associated with a granulomatous enterocolitis affects in first or third decade [26, 27]. Upper gastrointestinal involvement is rare with evidence of gastroduodenal ulcer with lymphocytic infiltration [28]. Clinical presentation similar to Crohn's disease. Colon specimen showed hemorrhagic mucosa and diffuse ulceration macroscopically and microscopically non-caseation granulomas, melanosis coli representing lipofuscin deposition. The BLOC-3-mediated dysfunction of the Rab proteins leading to mucosal inflammation indistinguishable between Crohn's and HPS 1, HPS 4. The Pathogenesis of endosomal trafficking explains mechanism of action of novel drug therapy warrants further research and also required to explore relation between Crohn's and HPS [25, 28] . Heřmanský-Pudlák syndrome colitis is refractory to standard treatment. Immunomodulatory such as infliximab-directed against tumor necrosis factor-a (TNF-a) is shown to be effective in HPS granulomatous colitis [29-31]. 


\section{EDORIUM Journals}

Heřmanský-Pudlák syndrome is differentiated from oculocutaneous albinism type 1 to 7-ocular albinism, both share skin and ocular manifestations. Heřmanský-Pudlák syndrome has additional features of platelet dysfunction, colitis and intestinal pulmonary fibrosis. Chediak-Higashi syndrome has oculocutaneous albinism or recurrent infections and easy bruising, differentiated from HPS due to neurological manifestations. Griscelli syndrome has partial albinism and immunodeficiency.

Treatment of Herrmanský-Pudlák syndrome consist of multidisciplinary approach: Recognizing clinical symptoms and diagnosis and preventing complication is the most important step in management.

The bleeding diathesis is a complication during surgery, dental extraction, or childbirth and may be treated with transfusion of platelets or whole blood. Desmopressin can be used prophylactic [32]. Hematological consult is initiated earliest. Managing complication during childbirth is challenging, NSAIDs and aspirin should be avoided and DDAVP or platelet transfusion does not prevent complications 100\% [33].

Regarding pulmonary fibrosis lung transplantation may remain the only effective treatment. Infection prophylaxis with influenza and pneumococcal vaccine is beneficial in preventing respiratory tract infections. Pirfenidone and nintedanib have shown to delay progression of HPS-PF. They have shown no benefit in milder disease of HPS 1 and HPS 4. Gene transfer for potential correction of BLOC-3 dysfunction needs more further studies and research [24]. Infliximab is useful in cases of HPS colitis.

Lifestyle modification, smoking cessation and daily exercise, avoidance of sun is also part of the management.

Monitoring lung function test and eye check-up periodically to recognize it in earlier stage. Consultation with a geneticist may aid families in understanding the disease and its implications for reproduction and health.

\section{CONCLUSION}

Heřmanský-Pudlák syndrome (HPS) should be considered as differential diagnosis in patients presenting with oculocutaneous albinism, nystagmus and dyspnea due to idiopathic interstitial disease, multiple skin squamous cell carcinoma excisions. The management of HPS is multidisciplinary approach with involvement of dermatologist, hematologist, respiratory physician and gastroenterologist and a geneticist is important to recognized early complication and monitor progression of disease. Monitoring organ function periodically, which ceroid deposits can impair is recommended.

\section{REFERENCES}

1. Hermansky F, Pudlak P. Albinism associcted with hemorrhagic diathesis and unusual pigmented reticular cells in the bone marrow: Report of two cases with histochemical studies. Blood 1959;14:162-9.

2. Witkop CJ, Nuñez Babcock M, Rao GH, et al. Albinism and Hermansky-Pudlak syndrome in Puerto Rico. Bol Asoc Med P R 1990 Aug;82(8):333-9.

3. Gahl WA, Brantly M, Kaiser-Kupfer MI, et al. Genetic defects and clinical characteristics of patients with a form of oculocutaneous albinism (Hermansky-Pudlak syndrome). N Engl J Med 1998 Apr 30;338(18):125864.

4. Witkop CJ, Almadovar C, Piñeiro B, Nuñez Babcock M. Hermansky-Pudlak syndrome (HPS): An epidemiologic study. Ophthalmic Paediatr Genet 1990 Sep;11(3):245-50.

5. Oh J, Ho L, Ala-Mello S, Amato D, et al. Mutation analysis of patients with Hermansky-Pudlak syndrome: A frameshift hot spot in the HPS gene and apparent locus heterogeneity. Am J Hum Genet 1998 Mar;62(3):593-8.

6. Langemeyer L, Ungermann C. BORC and BLOC-1: Shared subunits in trafficking complexes. Dev Cell 2015 Apr 20;33(2):121-2.

7. https://www.ncbi.nlm.nih.gov/books/ NBK1287/\#hps.molgen.TA

8. Huizing M, Helip-Wooley A, Westbroek W, GunayAygun M, Gahl WA. Disorders of lysosome-related organelle biogenesis: Clinical and molecular genetics. Annu Rev Genomics Hum Genet 2008;9:359-86.

9. Dell'Angelica EC. The building BLOC(k)s of lysosomes and related organelles. Curr Opin Cell Biol 2004 Aug;16(4):458-64.

10. Dennis MK, Delevoye C, Acosta-Ruiz A, et al. BLOC1 and BLOC-3 regulate VAMP7 cycling to and from melanosomes via distinct tubular transport carriers. J Cell Biol 2016 Aug 1;214(3):293-308.

11. Gahl WA, Brantly M, Kaiser-Kupfer MI, et al. Genetic defects and clinical characteristics of patients with a form of oculocutaneous albinism (Hermansky-Pudlak syndrome). N Engl J Med 1998 Apr 30;338(18):125864.

12. Carmona-Rivera C, Golas G, Hess RA, et al. Clinical, molecular, and cellular features of non-Puerto Rican Hermansky-Pudlak syndrome patients of Hispanic descent. J Invest Dermatol 2011 Dec;131(12):2394400.

13. Seward SL Jr, Gahl WA. Hermansky-Pudlak syndrome: Health care throughout life. Pediatrics 2013 Jul;132(1):153-60.

14. Toro J, Turner M, Gahl WA. Dermatologic manifestations of Hermansky-Pudlak syndrome in patients with and without a 16-base pair duplication in the HPS1 gene. Arch Dermatol 1999 Jul;135(7):77480.

15. Jardón J, Izquierdo NJ, Renta JY, García-Rodríguez O, Cadilla CL. Ocular findings in patients with the Hermansky-Pudlak syndrome (Types 1 and 3 ). Ophthalmic Genet 2016;37(1):89-94. 


\section{EDORiUM Journals}

www.ijcasereportsandimages.com

16. Huizing M,Gochuico BR, Gahl WA, Malicdan MCV. Molecular genetics of Hermansky-Pudlak syndrome. eLS 2017;1-10.

17. AmmannS, SchulzA, Krägeloh-MannI, etal.Mutations in $\mathrm{AP}_{3} \mathrm{D} 1$ associated with immunodeficiency and seizures define a new type of Hermansky-Pudlak syndrome. Blood 2016 Feb 25;127(8):997-1006.

18. Reference GH. Hermansky-Pudlak syndrome. 2017. [Available at: https://ghr.nlm.nih.gov/condition/ hermansky-pudlak-syndrome\#resources]

19. Iwata Y, Kobayashi T, Arima M, et al. Case of Japanese Hermansky-Pudlak syndrome patient with deeply invasive squamous cell carcinoma and multiple lesions of actinic keratosis on the face and neck. $J$ Dermatol 2017 Feb;44(2):219-20.

20. Hull S, Arno G, Holder GE, et al. The ophthalmic presentation of Hermansky-Pudlak 6. $\mathrm{Br} \quad \mathrm{J}$ Ophthalmol 2016 Nov;100(11):1521-4.

21. Scriver CR, Beaudet AL, Sly WS, Valle D. The metabolic basis of inherited disease. 6th edition. Japanese Journal of Human Genetics. 1989;34(3):253-3.

22. D'Andrea G, Chetta M, Margaglione M. Inherited platelet disorders: Thrombocytopenias and thrombocytopathies. Blood Transfus 2009 Oct;7(4):278-92.

23. Witkop CJ, Krumwiede M, Sedano H, White JG. Reliability of absent platelet dense bodies as a diagnostic criterion for Hermansky-Pudlak syndrome. Am J Hematol 1987 Dec;26(4):305-11.

24. Vicary GW, Vergne Y, Santiago-Cornier A, Young LR, Roman J. Pulmonary fibrosis in Hermansky-Pudlak syndrome. Ann Am Thorac Soc 2016 Oct;13(10):183946.

25. Schinella RA, Greco MA, Cobert BL, Denmark LW, Cox RP. Hermansky-Pudlak syndrome with granulomatous colitis. Ann Intern Med 1980 Jan;92(1):20-3.

26. Hussain N, Quezado M, Huizing M, et al. Intestinal disease in Hermansky-Pudlak syndrome: Occurrence of colitis and relation to genotype. Clin Gastroenterol Hepatol 2006 Jan;4(1):73-80.

27. Sofia MA, Sakuraba A, Rubin DT. Two complex cases of Hermansky-Pudlak syndrome highlight a potential biologic explanation for an associated Crohn's disease phenotype. ACG Case Rep J 2017 Jan 18;4:e14.

28. Lee AC, Poon $\mathrm{KH}$, Lo WH, Wong LG. Chronic ulcerative gastroduodenitis as a first gastrointestinal manifestation of Hermansky-Pudlak syndrome in a 10-year-old child. World J Gastroenterol 2008 May 14;14(18):2939-41.

29. Grucela AL, Patel P, Goldstein E, Palmon R, Sachar DB, Steinhagen RM. Granulomatous enterocolitis associated with Hermansky-Pudlak syndrome. Am J Gastroenterol 2006 Sep;101(9):2090-5.
30. Kouklakis G, Efremidou EI, Papageorgiou MS, Pavlidou E, Manolas KJ, Liratzopoulos N. Complicated Crohn's-like colitis, associated with HermanskyPudlak syndrome, treated with infliximab: A case report and brief review of the literature. $\mathrm{J}$ Med Case Rep 2007 Dec 8;1:176.

31. Felipez LM, Gokhale R, Guandalini S. HermanskyPudlak syndrome: Severe colitis and good response to infliximab. J Pediatr Gastroenterol Nutr 2010 Nov;51(5):665-7.

32. Wijermans PW, van Dorp DB. HermanskyPudlak syndrome: Correction of bleeding time by 1-desamino-8D-arginine vasopressin. Am J Hematol 1989 Mar;30(3):154-7.

33. Van Avermaete F, Muys J, Jacquemyn Y. Management of Hermansky-Pudlak syndrome in pregnancy and review of literature. BMJ Case Rep 2016 Nov 17;2016. pii: bcr2016217719.

$* * * * * * * * *$

\section{Author Contributions}

Sonali Someek Basu - Substantial contributions to conception and design, Analysis and interpretation of data, Drafting the article, Final approval of the version to be published

Pranav Kumar - Substantial contributions to conception and design, Acquisition of data, Drafting the article, Final approval of the version to be published

\section{Guarantor of Submission}

The corresponding author is the guarantor of submission.

\section{Source of Support}

None

\section{Consent Statement}

Written informed consent was obtained from the patient for publication of this case report.

\section{Conflict of Interest}

Authors declare no conflict of interest.

\section{Copyright}

(C) 2018 Sonali Someek Basu et al. This article is distributed under the terms of Creative Commons Attribution License which permits unrestricted use, distribution and reproduction in any medium provided the original author(s) and original publisher are properly credited. Please see the copyright policy on the journal website for more information. 
Access full text article on other devices

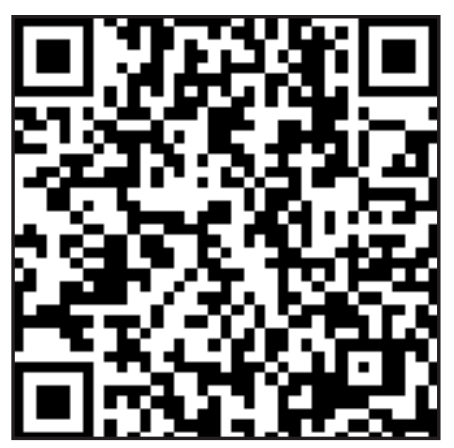

Access PDF of article on other devices

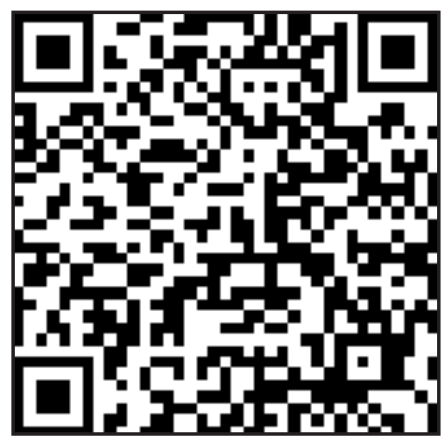

